\title{
Health Constraints and Farm Management Factors Influencing Udder Health of Dairy Cows in Malawi
}

\author{
Stanly Fon Tebug (Corresponding author) \\ Institute of Animal Breeding and husbandry, Christain Albrechts University Kiel \\ Olshausenstraße 40, 24098 Kiel, Germany \\ Tel: 49-431-880-2572 E-mail: stebug@tierzucht.uni-kiel.de; fon2tebug@yahoo.com \\ Gilson R. Njunga \\ Central Veterinary Laboratory, P. O. Box 527 Lilongwe, Malawi \\ E-mail: gilsonnjunga@yahoo.co.uk \\ Mizeck G. G. Chagunda \\ Future Farming Systems Group, Scottish Agricultural College, King's Buildings \\ West Mains Road, Edinburgh EH9 3JG Scotland, UK \\ E-mail: Mizeck.Chagunda@sac.ac.uk \\ Steffi Wiedemann \\ Institute of Animal Breeding and Husbandry, Christian-Albrechts-University Kiel \\ Olshausenstraße 40, 24098 Kiel, Germany
}

Tel: 49- 431-880-4533Ｅ-mail: swiedemann@tierzucht.uni-kiel.de

Received: February 3, $2012 \quad$ Accepted: February 20, $2012 \quad$ Online Published: April 20, 2012
doi:10.5539/jas.v4n6p136
URL: http://dx.doi.org/10.5539/jas.v4n6p136

This research was supported by World University Service of Canada (Malawi Office), under the capacity building program in partnership with Farmers Union of Malawi and Mzuzu Agriculture Development Division, Malawi.

\begin{abstract}
The aim of this study was to identify the major health problems and possible farm management practices which could be associated to the prevalence of mastitis in dairy cows kept in smallholder dairy farms in Malawi. A total of 140 randomly selected dairy farms were included in the study. Health problems were assessed using a semi-structured questionnaire and farm records. Physical examination and California Mastitis Tests (CMT) were used to determine the presence of clinical mastitis (CM) and subclinical mastitis (SCM). The most common diseases reported at farm level were mastitis 39.3\% (55/140) and East Coast Fever 15.7\% (22/140). Mastitis was the major udder disease and $52.0 \%(93 / 179)$ of the cows had at least one case of mastitis in the previous year. The prevalence of mastitis (positive result of physical examination or CMT) was significantly affected $(p<0.05)$ by history of mastitis, floor type, herd size, sanitation of stables and season of the year. Results of the present study suggest a need for targeted control measures against the major diseases identified. In addition, emphasis on management interventions with the aim to improve on the sanitation of stables is recommended in order to alleviate the negative impact of mastitis in dairy farms in Malawi.
\end{abstract}

Keywords: Smallholder dairy, Diseases, Mastitis, Management practices

\section{Introduction}

Smallholder dairy farming constitutes an important avenue for food production of animal origin in developing countries. In Malawi, smallholder dairy farming plays a central role in meeting the increasing demand for milk and milk products. In addition to the high nutritive value, milk production is an eminent income generating activity. Milk production is dominated by smallholder farmers who are organized in groups known as Milk Bulking Groups (MBGs) around the country's major cities. Farmers keep exotic breeds (mainly Holstein-Friesian 
and Jersey) and their crosses with indigenous Malawi zebu on dairy farms with comparable management practices throughout the country (Banda et al., 2011a). This market oriented dairy farming is regularly subjected to various constraints such as poor animal health, inadequate farm management and deficient marketing systems for milk and milk products (Banda et al., 2011a; Tebug et al., 2012). Moreover, these exotic cattle breeds and their crosses are more susceptible to local diseases which may result to high morbidity and mortality.

Inflammation of the udder also known as mastitis has been reported as major animal health concern in smallholder dairy production systems. The prevalence of mastitis has been reported to vary with cattle breeds as well as farm management and environmental factors (Karimuribo et al., 2008; Phiri et al., 2010). The prevalence of mastitis assessed using California Mastitis Test (CMT) ranged from 38.1 to $75.9 \%$ in cows and 30.4 to $46.2 \%$ quarters in dairy cows in smallholder farms Ethiopia and Tanzania (Mungube et al., 2005; Karimuribo et al., 2008). Moreover, Mungube et al. (2005) estimated that 159 liters of milk per lactation could be gained by reducing subclinical form of mastitis from high (75.0\%) to low (48.1\%) prevalence rate in crossbred dairy farms in Ethiopia. In addition to reduction in milk yield, losses due to mastitis include cost incurred in treating sick cows, change in milk composition, decrease in milk quality, and increase in replacement of dairy cows (Thrustfield, 2007).

Considering the current focus on dairy cattle breed improvement as a means to improve on milk supply in Malawi, potential production constraints including animal health need to be identified and addressed. Hence, this paper reports on major health problems and possible farm management factors associated with the detection of both clinical and subclinical mastitis in dairy cattle reared by smallholder farmers in Malawi.

\section{Materials and Methods}

\subsection{Study Area and Participating Farms}

Data used in this study was collected from December, 2010 to June 2011 in two of the six administrative districts (Mzimba and Nkhata Bay) of the Northern Region of Malawi. Most (over 90\%) of the dairy cattle population in the region is found in these districts (Banda et al., 2011b). The area is situated between latitude $11-13^{\circ} \mathrm{S}$, longitude $33-35^{\circ} \mathrm{E}$ and has a subtropical climate with an average altitude of about 1, 200 meters above sea level. The rainy season lasts from November to April with a mean annual rainfall of $1,750 \mathrm{~mm}$. The dry season lasts from April to October and the average annual temperature is $20^{\circ} \mathrm{C}$. A table of random numbers (Thrustfield, 2007) was used to randomly select 140 farms from a 684 registered farmers at Mzuzu Agricultural Development Division. This provided $20.5 \%$ of the target population and animals in each farm were included in the study.

\subsection{Survey for Health Problems and Examination for Mastitis}

A pre-tested and structured questionnaire was used to collect information for the retrospective survey on animal health problems and farm characteristics. Farms were visited on a single day. Information contained in the questionnaire included herd composition, milking practices, floor type, sanitation, grazing system practiced. Farmers were asked to give a detailed description of diseases or health conditions that occurred on their within the previous year. Information from farm record was used when available. Health problems were grouped according to their similarities and body systems affected as previously described by Lema et al. (2001).

Alongside the questionnaire survey, udder and milk of all lactating cows present on each farm on the day of the farm visit were examined for both clinical and subclinical mastitis and non-functional or blocked (NFB) quarters. Changes in milk consistency or colour, abnormal secretions, size or consistency, increase temperature or pain upon palpation were considered indicative of clinical mastitis (CM). A cow was deemed to have CM if at least one quarter had either of the clinical finding indicative for clinical mastitis during the study. California Mastitis test (CMT; Bovi-Vet ${ }^{\mathrm{TM}}$, Kruuse, Germany) was carried out on all quarters with the exception of NFB. After the quarter was washed and dried, the first few squirt of milk was discarded and a few strips of milk were collected in a strip cup and checked for gross changes. About $5 \mathrm{ml}$ of milk was collected from each quarter into the respective wells of the CMT paddle and an equal volume of CMT reagent was added into each well. The paddle was swirled to thoroughly mix the contents for about 10 seconds. According to the amount of gel formed, the reaction was visually scored as "negative" $(0)$, trace " $(+)$, "weak positive" $(++)$, "distinct positive" $(+++)$ or "strong positive" $(++++)$. Subclinical mastitis (SCM) was deemed present in a cow if a CMT score of + to ++++ was noted in one quarter. All examinations and data collection for this study were carried out by the same team comprising the principal investigator and a dairy extension personnel.

\subsection{Statistical Analysis}

Data obtained was entered into Microsoft Excel 2007 (Microsoft Corp) and later transferred in R statistical software (R Development Core Team (2011)). Multivariable logistic regression and odds ratio were used to assess the association between potential farm management factors and prevalence of mastitis in cows. The result of mastitis examination (positive or negative clinical examination and CMT) was used as the independent 
variable while management factors were considered as dependent variables. The entire sampled population was used for the analyses of health problems while data from 18 lactating cows including those from 5 farms were omitted in the analysis management factors that could influence udder health because of missing values.

\section{Results}

\subsection{Farm Characteristics and Health Problems}

Over $50 \%$ of dairy animals in the selected farms where made up of lactating cows (Table 1). All farmers in the study practiced hand milking and one udder quarter is usually left for the un-weaned calf to suckle after milking is completed. The most prevalent disease groups were udder and infectious diseases. Mastitis and East Coast Fever were reported in $39.3 \%$ and $15.7 \%$ of farms included in the study, respectively (Table 2, Figure 1).

\subsection{Udder Health and Associated Farm Management Practices}

A total of 152 lactating cows and 608 quarters (teats) were subjected to clinical examination and California Mastitis Test. Clinical mastitis was observed in 17 cows (11.2\%) while subclinical mastitis was detected in 78 $(51.3 \%)$ cows and $263(43.6 \%)$ quarters. Four cows $(2.6 \%)$ had non-functional or blocked quarters, with a total of 5 teats $(0.8 \%)$ affected. The percentage of cows having mastitis (both clinical and subclinical) was significantly $(\mathrm{p}<0.05)$ affected by history of mastitis, floor type, herd size, sanitation of stable and season of the year (Table 3). A higher percentage mastitis were observed in cows that had at least one case of mastitis in the previous year, those housed on cemented floors as well as dirty and wet floors in cows during the raining season.

\section{Discussions}

\subsection{Farm Characteristics and Health Constraints}

The herd size of one to six cattle with an average 2.4 is comparable with 2.2 to 3.5 cattle per farm reported in other Regions of Malawi (Chagunda et al., 2006; Banda et al., 2011a). However, very little increase in average herd size was observed ( 2.4 vs. 2.2) when compared to results of a previous study in the same study area two years earlier (Tebug et al., 2012). The relatively stable herd size observed might be due to low calving rates based on artificial insemination records, which is prominent in the Northern Region of Malawi (Banda et al., 2011b). Moreover, other studies in carried out in smallholder dairy farms in East African countries including Malawi identified inefficient reproductive management as a major challenge to dairy development (Banda et al., 2011b; McDermott et al., 2010; Tebug et al., 2012).

Results of this study revealed that mastitis and East Coast Fever were the major health constraints encountered in dairy farms, with more than half the number of cows reported to have had mastitis at least once in the previous year. This result agrees with Tebug et al. (2012) where poor animal health was found to be second major constraints to 210 smallholder dairy farmers two years earlier (Tebug et al., 2012). Furthermore, mastitis was the most reported cause of morbidity in 65 studies carried out in smallholder dairy farms in East and South African (ESA) countries (Lema et al., 2001; Phiri et al., 2010). The high prevalence of mastitis in farms is not only a hygienic problem, but also lowers income of the dairy producers and decreases animal welfare. Metabolic diseases were among the least reported health problems. This could be attributed to low milk production of dairy animal estimated at 5-15 liters per day per cow (Chagunda et al., 2006; Tebug et al., 2012) or to the lack of sufficient understanding of metabolic disease by farmers.

\subsection{Udder Health and Associated Farm Management Practices}

The prevalence of mastitis in our study was lower at quarter (cow) level 43.3 vs. $68 \%$ (59 vs. 61\%) but was within the range $22.0-84.5 \%$ (2.1 - 90.0\%) reported by fifteen authors in ESA countries (Phiri et al., 2010). All farmers left one quarter for the un-weaned calf to suckle after milking is completed. According to Phiri et al. (2010), residual calf suckling is negatively associated to mastitis and could explain the relatively lower detection rate observed. However, there were several factors associated to higher prevalence of mastitis in our study.

The percentage of cows having mastitis was higher in cows with a history of mastitis. This is in agreement with the report of Mungube et al. (2004) and Abera et al. (2010) in Ethiopia. It was however different from Abera et al. (2012) who reported no significant influence of previous history on the detection of mastitis in dairy cows.

Cows housed on concrete floors tend to have more mastitic quarters than those housed on earth and brick floors. This observation differs from that of Abera et al. (2010). Cow pens in the study area are mostly roofed with thatches which do not usually cover the entire pens and leak during the raining season. When these pens are not cleaned on regular basis and in the presence of manure and dairy slurry, concrete floors as opposed to earth floors favor the accumulation of moisture, hence, a good milieu for bacteria to thrive.

Similarly, the percentage of cows having mastitis was found to be lower in cows housed in stables with clean and dry floors compared to cows housed in dirty and wet floors. The same observation was made in farms with more 
than two animals as oppose to those with less than three animals and suggest that sanitation was a major predisposing factor for the prevalence of mastitis in dairy cows in Malawi. This suggestion is in line with Kudi et al. (2009) who reported variation in bacteria number between different floor beddings. The same author identified a relationship between the number of bacteria within the bedding material and the number of bacteria on the teat end of cows. Hence, need exist to improve on farm management practices aimed reducing contact of teat with mastitis causing pathogens from the cow's environment in order improve on udder health in dairy cows in Malawi.

Milk production in Malawi increased by 1.1\% every year between 1999 and 2009 and the per capita milk consumption is estimated at 4.5-6 kg (DAHLD, 2005; FAO, 2011). This increase is far below the $4.0 \%$ annual increase for developing countries projected between 1999 and 2020 by Delgado et al. (2001). In order to attain the projected per capita milk consumption of $30 \mathrm{~kg}$ for sub-Saharan Africa by 2020 (Delgado et al. 2001), more effort is needed to increase milk production and to reduce losses along the entire dairy production chain. According to Chimbaza (2011), poor milk quality is a major cause for losses and reduced earnings by smallholder farmers in Malawi. Further, Chindime (2007) estimated that $17 \%$ of milk produced and sold through the formal market channel is rejected because of poor quality. Our results reveal that mastitis and infectious disease such as East Coast Fever are the most frequent health constraints to smallholder dairying in Malawi. Therefore, disease prevention and control measures taking into consideration factors identified are recommended as a means to increase milk production as well as producers' earnings and to improve on the quality of milk sold to consumers.

\section{References}

Abera, M., Demie, B., Aragaw, K., Regassa, F., \& Regassa, A. (2010). Isolation and identification of Staphylococcus aureus from bovine mastitic milk and their drug resistance patterns in Adama town, Ethiopia, Journal of Veterinary Medicine and Animal Health, 2(3), 29-34.

Abera, M., Habte, T, Aragaw, K., Asmare, K., \& Sheferaw, D. (2012). Major causes of mastitis and associated risk factors in smallholder dairy farms in and around Hawassa, Southern Ethiopia. Tropical Animal Health and Production. http://dx.doi.org/ 10.1007/s11250-011-0055-3

Banda, L. J., Gondwe, T. N., Gausi, W., Masangano, C., Fatch, P., Wellard, K., Banda, J. W., \& Kaunda, E. W. (2011a). Challenges and Opportunities of Smallholder Dairy Production Systems: A Case Study of Selected Districts in Malawi. Livestock Research for Rural Development, 23(226). [Online] Available: http://www.lrrd.org/lrrd23/11/band23226.htm (January 27, 2012).

Banda, L. J., Kamwanja, L. A., Chagunda, M. G. G., Ashworth, C. J., \& Roberts, D. J. (2011b). Status of dairy cow management and fertility in smallholder farms in Malawi. Tropical animal Health and Production. http://dx.doi.org/10.1007/s11250-011-9972-4

Chagunda, M. G. G., Msiska, A. C. M., Wollny, C. B. A., Tchale, H., \& Banda, J. W. (2006). An analysis of smallholder farmers' willingness to adopt dairy performance recording in Malawi. Livestock Research for Rural Development, 18(66). [Online] Available: http://www.lrrd.org/lrrd18/5/chag18066.htm (January 27, 2012).

Chimbaza, T. (2011). Milk keeping quality in Malawi. End of project report on Small holder Dairy Production in Malawi: current Status and future Solutions. Lilongwe, Malawi.

Chindime, S. (2007). Milk bulking groups baseline assessment report. Prepared for Malawi Dairy Development Alliance (CREMPA, MDFA, and Land O' Lakes), Mwai House, Lilongwe, Malawi.

DAHLD. (2005). Policy document on Livestock in Malawi (Agriculture Communication Branch, Ministry of Agriculture, Malawi).

Delgado, C., Rosegrant, M., Steinfeld, H., Ehui, S., \& Courbois, C. (2001). Livestock to 2020: the next food revolution. Outlook on Agriculture, 30(1), 27-29. http://dx.doi.org/10.5367/000000001101293427

FAO. (2011). FAO Statistic Division. [Online] Available: http://faostat.fao.org (Accessed, September 3, 2011).

Karimuribo, E. D., Fitzpatrick, J. L., Swai, E. S., Bell, C., Bryant, M. J., Ogden, N. H., Kambarage, D. M., \& French, N. P. (2008). Prevalence of subclinical mastitis and associated risk factors in smallholder dairy cows in Tanzania. Veterinary Record, 163(1), 16-21. http://dx.doi.org/10.1136/vr.163.1.16

Kudi, A. C., Bray, M. P., Niba, A. T., \& Kalla, D. J. U. (2009). Mastitis Causing Pathogens within the Dairy Cattle Environment. International Journal of Biology, 1(1), 3-13.

Lema, M., Kassa, T., \& Tegegne, A., (2001). Clinically manifested major health problems of crossbred dairy herds in urban and periurban production systems in the central highlands of Ethiopia. Tropical Animal Health and Production, 33(2), 85-93. http://dx.doi.org/10.1023/A:1005203628744

McDermott, J. J., Staal, S. J., Freeman, H. A., Herrero, M., \& Van de Steeg, J. A. (2010). Sustaining 
intensification of smallholder livestock systems in the tropics. Livestock Science, 130, 95-109. http://dx.doi.org/10.1016/j.livsci.2010.02.014

Mungube, E. O., Tenhagen, B. A., Regassa, F., Kyule, M. N., Shiferaw, Y., Kassa, T., \& Baumann, M. P. O. (2005). Reduced Milk Production in Udder Quarters with Subclinical Mastitis and Associated Economic Losses in Crossbred Dairy Cows in Ethiopia. Tropical Animal Health and Production, 37, 1573-7438. http://dx.doi.org/10.1007/s11250-005-7049-y

Mungube, E. O., Tenhagen, B-A., Kassa, T., Regassa, F., Kyule, M. N., Greiner, M., \& Baumann, M. P. O. (2004). Risk factors for dairy cows mastitis in the central highlands of Ethiopia. Tropical Animal Health and Production, 36(5), 463-472. http://dx.doi.org/ 10.1023/B:TROP.0000034999.08368.f3

Phiri, B. J., Benschop, J., \& French, N. P. (2010). Systematic review of causes and factors associated with morbidity and mortality on smallholder dairy farms in Eastern and Southern Africa. Preventive Veterinary Medicine, 94(1-2), 1-8. http://dx.doi.org/ 10.1016/j.prevetmed.2010.01.012

R Development Core Team. (2011). R: A language and environment for statistical computing. R Foundation for Statistical Computing, Vienna, Austria. ISBN 3-900051-07-0, URL http://www.R-project.org/

Tebug, S. F., Kasulo, V., Chikagwa-Malunga, S., Wiedemann, S., Roberts, D. J., \& Chagunda, M. G. G. (2012). Smallholder dairy production in Northern Malawi: production practices and constraints. Tropical Animal Health and Production, 44(1), 55-62. http://dx.doi.org/ 10.1007/s11250-011-9887-0

Thrustfield, M. (2007). Veterinary Epidemiology ( $3^{\text {rd }}$ ed.). Blackwell Science Ltd, Oxford, UK.

Table 1. Average herd composition of 140 smallholder dairy farms (December 2010-June 2011)

\begin{tabular}{lll}
\hline Class & Composition per farm ( Mean, range) & Total number of cattle (number, \%) \\
\hline Lactating cows & $1.2(0-3)$ & $170(51.1)$ \\
Non lactating cows & $0.1(0-2)$ & $9(2.7)$ \\
Heifers (post weaned, pre-calving) & $0.4(0-2)$ & $49(14.7)$ \\
Bulls (post weaned) & $0.2(0-2)$ & $22(6.6)$ \\
Calves (pre-weaned, male and female) & $0.6(0-2)$ & $83(25.1)$ \\
Total & $2.4(1-6)$ & $333(100)$ \\
\hline
\end{tabular}

Table 2. Distribution common diseases and conditions as reported per smallholder dairy farm (2010-2011)

\begin{tabular}{llll}
\hline Disease group & Diseases or conditions & Number of cases & Number of farms (\%) \\
\hline Udder diseases & Mastitis & 88 & $55(39.29)$ \\
& Blocked quarters & 5 & $4(3.57)$ \\
Specific & East coast Fever & 27 & $22(15.71)$ \\
infectious & Infectious bovine & 10 & $8(5.71)$ \\
diseases & keratoconjunctivitis (Pink eye) & & \\
& Black quarter & 10 & $6(4.29)$ \\
Locomotory & Lumpy skin disease & 1 & $1(0.71)$ \\
conditions & Lameness & 7 & $5(3.57)$ \\
Respiratory & Enlarged joints & 1 & $1(0.71)$ \\
conditions & Difficult breathing & 4 & $4(2.86)$ \\
Metabolic & Milk fever & 2 & $2(1.43)$ \\
diseases & & 3 & $3(2.14)$ \\
Gastrointestinal & Worms & & \\
disorders & Diarrhea & 10 & $7(5.00)$ \\
& Ingestion of plastic objects & 4 & $4(2.86)$ \\
Reproductive & Retained Placenta & 8 & $1(0.71)$ \\
diseases & Abortions & 2 & $8(5.71)$ \\
& Difficult birth & 2 & $2(1.43)$ \\
& Repeated breeders & 2 & $2(1.43)$ \\
Others & Still birth & 1 & $2(1.43)$ \\
& Unknown & 5 & $1(0.71)$ \\
& Abscess & 1 & $5(3.57)$ \\
\hline
\end{tabular}


Table 3. Management practices associated with the detection of mastitis in dairy cows (152 cattle from 135 farms)

\begin{tabular}{|c|c|c|c|c|c|c|c|}
\hline Variable & Level & $\begin{array}{l}\text { Number of } \\
\text { examined }\end{array}$ & $\begin{array}{l}\text { ows } \\
\text { With } \\
\text { mastitis (\%) }\end{array}$ & Coef. & SE & $\begin{array}{l}\text { Odds ratio } \\
(95 \% \mathrm{CI})\end{array}$ & P-value \\
\hline \multirow{4}{*}{$\begin{array}{l}\text { History of } \\
\text { Mastitis within } \\
\text { the last 1year } \\
\text { Feeding method }\end{array}$} & Absent & 91 & $47(51.6)$ & & & & \\
\hline & Present & 61 & $42(68.9)$ & 1.168 & 0.424 & $3.21(-0.07,0.78)$ & 0.006 \\
\hline & Grazing & 22 & $18(81.8)$ & & & & \\
\hline & $\begin{array}{l}\text { Stall } \\
\text { feeding }\end{array}$ & 130 & $71(54.6)$ & -0.751 & 0.671 & $0.47(-2.17,0.51)$ & 0.262 \\
\hline \multirow[t]{2}{*}{ Floor type } & Earth & 135 & $76(56.3)$ & & & & \\
\hline & Cement & 17 & $13(75.5)$ & 1.880 & 0.764 & $6.56(0.48,3.52)$ & 0.0138 \\
\hline \multirow[t]{2}{*}{ Herd size } & $\geq 3$ & 58 & $35(60.3)$ & & & & \\
\hline & $<3$ & 94 & $54(57.4)$ & -1.189 & 0.467 & $0.30(-2.14,0.30)$ & 0.011 \\
\hline \multirow{2}{*}{$\begin{array}{l}\text { Sanitation of } \\
\text { Stable }\end{array}$} & Good & 63 & $26(41.3)$ & & & & \\
\hline & Bad & 89 & $63(70.8)$ & 1.514 & 0.428 & $4.55(0.70,2.38)$ & 0.000 \\
\hline \multirow{4}{*}{$\begin{array}{l}\text { Number of } \\
\text { Milking } \\
\text { practices } \\
\text { Season }\end{array}$} & $\leq 3$ & 78 & $55(70.5)$ & & & & \\
\hline & $>3$ & 74 & $34(45.9)$ & -0.572 & 0.417 & $0.56(-1.39,0.24)$ & 0.170 \\
\hline & Dry & 37 & $11(29.7)$ & & & & \\
\hline & Raining & 115 & $78(67.8)$ & 1.592 & 0.516 & $4.91(0.61,2.65)$ & 0.002 \\
\hline
\end{tabular}

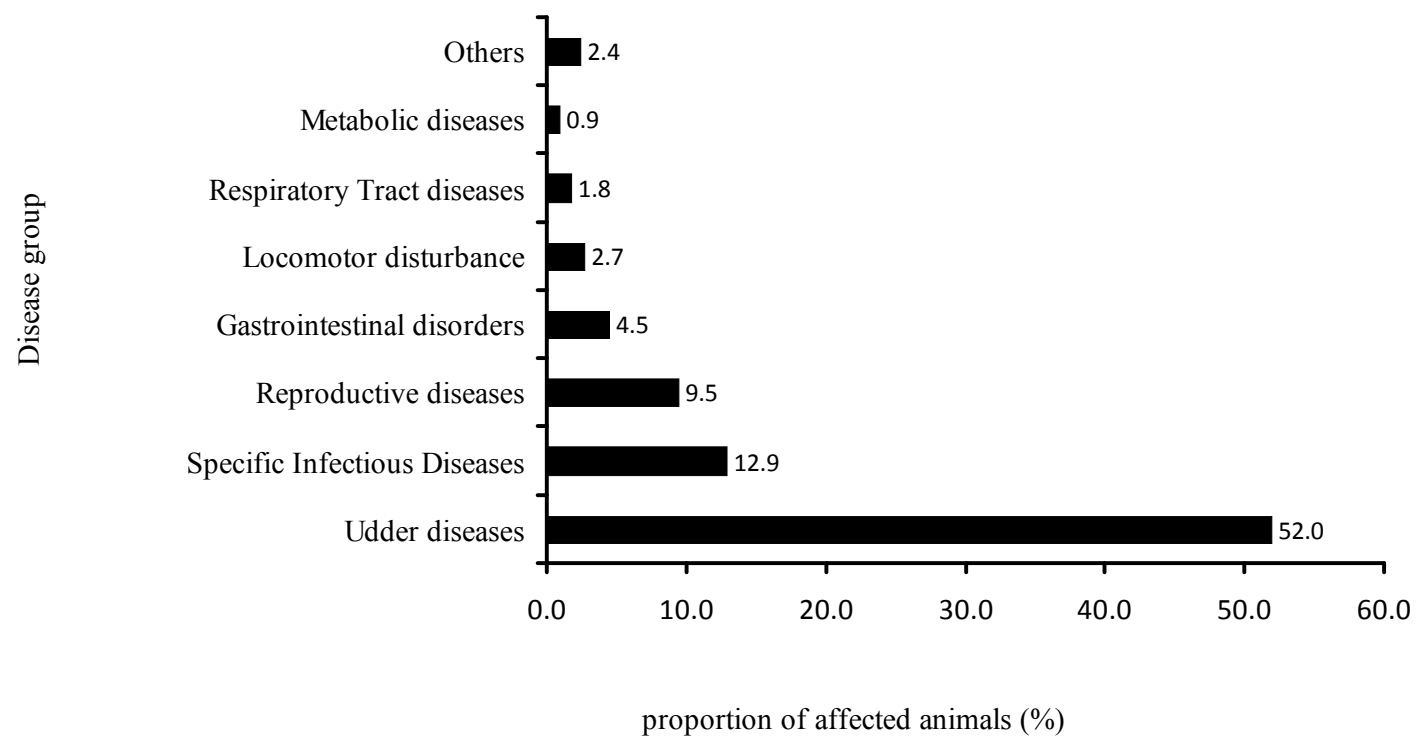

Figure 1. Proportion of affected animals per susceptible disease group as reported in 140 dairy farms 